Article

\title{
Curating Indigenous Knowledge and Practices for Sustainable Development: Possibilities for a Socio-Ecologically-Minded University
}

\author{
Marcellus Mbah ${ }^{1, *(1)}$ and Charles Fonchingong ${ }^{2(1)}$ \\ 1 Institute of Education, Nottingham Trent University, Nottingham NG1 4FQ, UK \\ 2 School of Nursing, Midwifery and Social Work, Canterbury Christ Church University, Canterbury, \\ Kent CT1 1QU, UK \\ * Correspondence: marcellusmbah@gmail.com
}

Received: 5 March 2019; Accepted: 23 July 2019; Published: 6 August 2019

\begin{abstract}
Higher education continues to play an integral role in fostering regional development and this is underpinned by the concept that universities possess a social responsibility as proponents of progress in relation to society's socio-economic, political and environmental challenges. Different approaches have been articulated but none seems to provide a useful framework to support African universities' contribution to development in their regions. This paper interrogates the idea of the ecological university and moves on to posit the possibility for a socio-ecological premise to meet environmental and societal needs, based on a symbiotic relationship between indigenous practices and a university's capacity to engender sustainable development. Findings from an in-depth analysis of participants' transcripts drawn from qualitative responses depict indigenous knowledge and practices which can galvanise environmental and societal sustainability, and bring to the fore the idea of the socio-ecologically-minded university.
\end{abstract}

Keywords: indigenous knowledge; higher education; sustainable development; socio-ecologicallyminded university

\section{Introduction}

In the context of African development, the university continues to metamorphose in its role in relation to its local, regional, national and continental commitment [1-3]. Historical consideration and socio-political factors that have shaped the African continent continue to play a role in inhibiting the efficacy of African higher education institutions (HEIs) in contributing to the sustainable development of their communities, particularly in a culturally-preservative manner. The period of decolonisation of education in the 1960s was intended to empower and promote equity but was flawed because most universities, whose focus was to reconstruct the economy through academic awareness of the population, were mostly elite institutions, thereby alienating native stakeholders [3-5]. Similarly, there was a systematic failure to curate knowledge, and develop curricula with adaptations of indigenous cultural values and practices at its foundation. In more recent times, governing bodies such as the United Nations have highlighted the need for inclusive education which protects indigenous people, and their practices in policy drives toward sustainable development [6-9]. However, systemic issues persist around the governance and quality of universities in Africa to implement strategies that address a wide array of problems hindering the continent and its inhabitants [10-12]. Increasingly, universities are grappling with their civic and social responsibilities amidst funding limitations [13-15]. Despite these shortcomings, contemporary universities in Africa have not been deterred from their integral mission of creating and disseminating knowledge for the common good of the respective regions $[1,3,16]$. 
In this regard, a comprehensive inference justifies the need to amalgamate current models of university education in Africa with indigenous culture and practices, aimed at fostering sustainable development, which can be framed within the context of meeting societal and environmental needs [9,17-20]. Whilst the notion of sustainable development is subjected to varying interpretations and contexts, this paper underscores the premise of the socio-ecological university, needed to address the range of complex issues impacting on development in Africa. This paper argues that embedding indigenous knowledge and reconceiving the curricula in partnership with universities are critical in harnessing the benefits of the natural environment and societal advancement.

\section{Theoretical Framework}

The core premise of this paper is rooted within a departure from the model of the ecological university. The ecologically-oriented university as proposed by Barnett [21] is a higher education institute unlike the research and entrepreneurial university, characterised as one "for-others" (pp.452). This signifies concern for the sustainability and progress of different ecologies, as well as maximising its resources for sustainable development. The method of engagement of the ecological university goes beyond the acquisition of knowledge for knowledge's sake and aims to form a wide and varied network, to ensure a balanced and equitable approach to the development of itself, the local community, and the environment at large $[18,21,22]$. This is driven by the dedication to the enlargement of human knowledge through an inclusive and intersectional approach, and the formation of university structures, both physically and pedagogically [23-25]. It appreciates the varied identities, social and cultural capital of the stakeholders from the local and global community as co-creators, implicated in knowledge dissemination by the university, and assumes responsibility for promoting an ecological literacy, for the benefit of students and community stakeholders locally, and beyond $[18,26]$. The ecological university can be said to be fluid in nature and responds to the culture and changing conditions of its immediate ecology. It seeks to offer an education that equip learners to be informants and catalysts of social, economic and environmental change $[27,28]$.

Although a university may utilise the incentives offered because of its ecological ethos, there is need to look beyond the ecological premise by calibrating the university's social and civic responsibility towards sustainable development, locating its local and global ecologies as ethical priorities [13,29-32]. These priorities, which the ecologically minded university thrive on, can lead to the curation of a comprehensive knowledge system in higher education institutions (HEIs), equipped to respond to the need for a sustainable future, with specific focus on ongoing environmental and societal change. Ultimately, the idea of the socio-ecological university can be conceived and engendered through the South African principle of ubuntu (a philosophy of self-help and communal solidarity). This principle in a purely management style, can be influenced by social, academic and environmental considerations [33-35]. Drawing on ubuntu within an academic context, the socio-ecological university is premised on a symbiotic relationship, seen as a better approach to tackling sustainable development through better understanding of the local context and best practices in knowledge production and dissemination.

The symbiotic feature of the socio-ecological university is epitomised by a mutually beneficial narrative of social ethics, morality and the importance of local context and stakeholder engagement. It promotes the notion that the individual is dependent and affected by the other which is reflected in the research and teaching practices of the institution. Such an approach underlines the relevance of local indigenous knowledge and mitigates the mono-faceted dogmatic Eurocentric epistemology inherent in modern education [36-38]. This positioning of the socio-ecological university can also lead to pedagogical intersectionality in higher education, founded upon a concerted shift in research paradigms from current systems, to one that engages with the society and environment in which universities are situated $[9,15,39,40]$. Potential outcomes include the development of diversified and environmentally friendly interventions and tools in various disciplines, as well as the optimisation of cultural assets, and indigenous expertise for sustainable development. 


\section{Methodology}

The case is being made for small-scale, yet significant studies and methodological approaches to develop a contextual understanding of how communities in the global south interact with higher education to address local needs for sustainable development. The layers of engagement and evolving relationship also needs deeper scrutiny of how local knowledge systems and practices can be curated, in a synergistic partnership leading on to strategic outcomes for the common good.

In order to understand the interaction between higher education, indigenous knowledge and sustainable development, an instrumental case study [41,42] was employed. This approach was most useful in generating rich data by capturing and drawing meanings from the views of university and community participants within a bounded system.

Fieldwork took place in the month of July 2016 and the site of the research was the Buea municipality in the English speaking region of Cameroon consisting of 85 villages, spread across a surface area of 870 Sq.km, with an estimated population of 200,000 inhabitants (Figure 1). A different municipality and perhaps in the French speaking part of Cameroon could have been chosen for this research but was decided against due to the language barrier and the potential additional costs of securing translation. The targeted municipality consists of a state-owned university with a combined student and staff population of about 18,000 at the time the study was conducted.

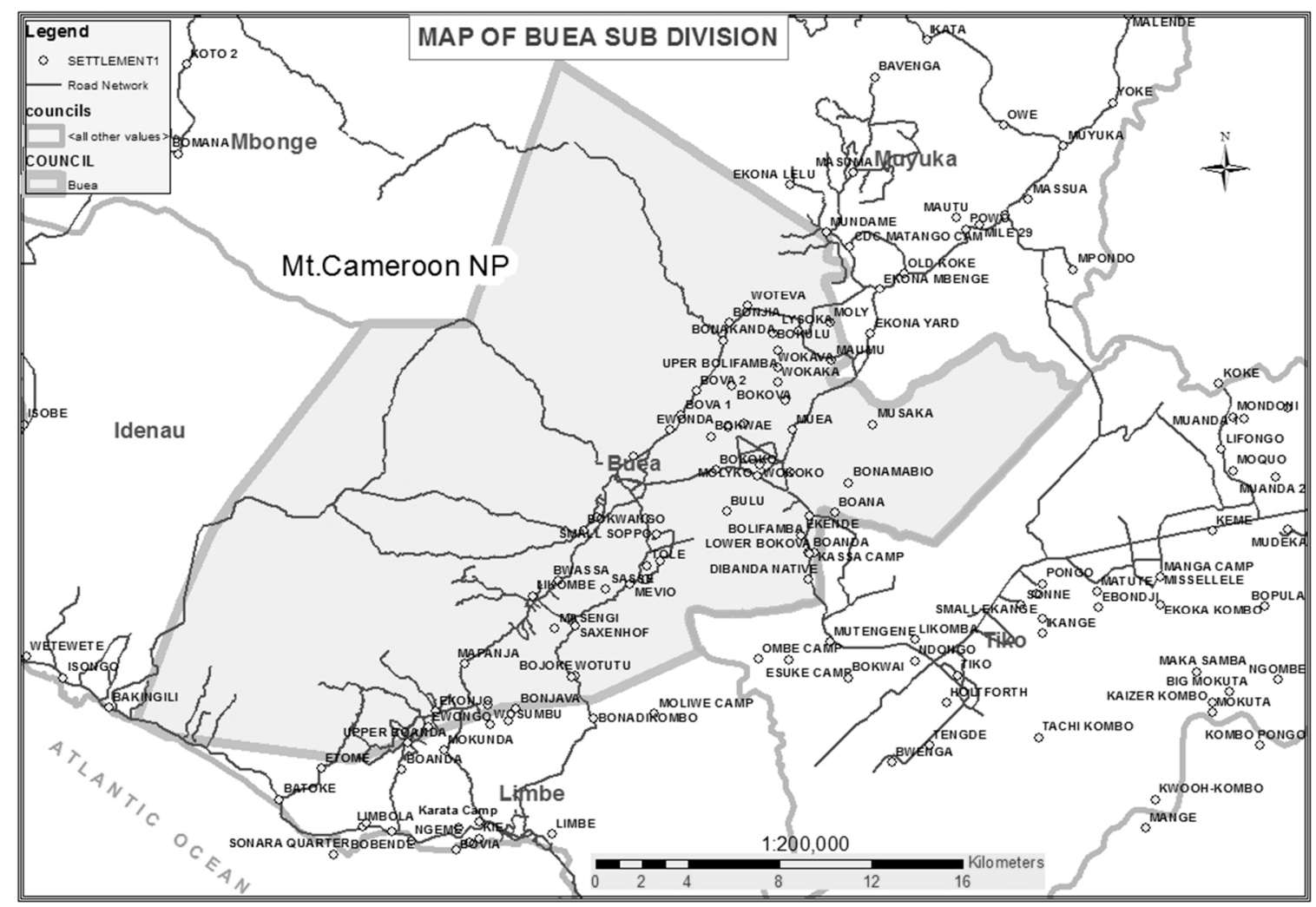

Figure 1. Map of the study area (Buea municipality) and surrounding study sites.

This university emerged from Cameroon's higher education reforms of 1993 [43] with a mission to contribute to national development amongst others. It is worth noting that Cameroon's development plan is anchored on sustainable development and the role of education in national growth strategies. In total, sixteen participants were sought from a variety of disciplines and professions in order to capture heterogeneity in experience. These participants were recruited through a mix of purposive and snow-ball sampling. The sampling approaches were informed by judgements of typicality and the recruitment of informants able to shed light on social and other networks [44,45]. 
Given that the inquiry process entailed responsive, semi-structured interviews with university and community stakeholders [46], participants responded to a number of research questions, which included their understanding of indigenous knowledge systems, linkages and partnerships for local development, university's community engagement and social development challenges. Audio recordings of the interviews were transcribed and analysed thematically $[47,48]$. Whilst the process of thematic analysis involves coding, cataloguing codes into themes and building arguments, the analysis was largely informed by the narratives of participants. Throughout the analysis, significant responses and strategies in the narratives of participants which reveal the underlying relevance of indigenous knowledge and practices to sustainable development were underscored. Most importantly, the emerging analysis were checked against participant understandings and situated within the research context [49]. The research participants with pseudonyms have been represented (Table 1):

Table 1. Profile of research participants.

\begin{tabular}{ccc}
\hline No. & Participant & Profession \\
\hline 1 & Paul & A support worker at a local university and village elder \\
2 & Peter & Researcher in sociology at a local university \\
3 & Terence & Researcher in gender studies at a local university \\
4 & Linus & Traditional ruler in one of the villages \\
5 & Genesis & A quarter head and member of a traditional council \\
6 & David & A retired clergyman and villager elder \\
7 & Agnes & A PhD student at a local university \\
8 & Lyonga & Traditional ruler in one of the villages \\
9 & Andrew & Traditional ruler in one of the villages \\
10 & Elaine & Director of a local NGO on local development \\
11 & Toni & Researcher in tropical diseases at a local university \\
12 & Sharon & Director of a local NGO on local development \\
13 & Alain & Community elder and a clergyman \\
14 & Tabe & A village elder \\
15 & Fred & Traditional ruler in one of the villages \\
16 & Federick & Traditional ruler in one of the villages \\
\hline
\end{tabular}

Following the analysis of the transcripts of audio recordings, direct quotations representing indigenous insights have been used to support some of the findings in the ensuing sections and where this is the case the quotations have been followed by the participants' name (pseudonym) and profession.

\section{Findings and Discussion}

Following a comprehensive analysis of the research data, findings captured three main themes, namely: evidencing indigenous practices for sustainable development, challenges associated with the maximisation of indigenous practices and the possibilities of a socio-ecologically minded university.

\section{Evidencing Indigenous Practices for Sustainable Development}

Agricultural practices, poverty alleviation, rural livelihoods, community development and inclusion are interconnected in ensuring sustainable development [17,50-52]. These practices form the basis for local-level decision making in agriculture, health care, food preparation, education, natural resource management, and a host of other activities in rural communities. Furthermore, relevant indigenous practices can be part of broad-based approaches and processes aimed at meeting the need for sustainable development [6-9]. In the context of the premise underpinning this paper, findings provide evidence of indigenous practices, which can be associated with initiatives toward sustainable development. This evidence touches on environmental and societal aspects, which are key themes from the data, as depicted (Table 2). The quotations mentioned below have been included solely to illustrate the themes: 
Table 2. Evidencing indigenous practices toward environmental and societal sustainability.

\begin{tabular}{|c|c|}
\hline \multicolumn{2}{|c|}{ Evidencing Indigenous Practices toward Environmental and Societal Sustainability } \\
\hline Practices That Support Environmental Sustainability & Practices That Support Societal Sustainability \\
\hline - Indigenous approach to bio-conservation: & - Indigenous approach to diplomacy and morality: \\
\hline $\begin{array}{l}\text { "Those red feathers on the hats of our notables are not just from any } \\
\text { birds, so it is of the interest of our culture to conserve those birds" } \\
\text { (Terence is a researcher at a local university) }\end{array}$ & $\begin{array}{l}\text { "There are intermarriages between chiefdoms. That way, there } \\
\text { is a diplomatic link such that if there is a boundary dispute that } \\
\text { would be minimised because the people will say 'oh, don't } \\
\text { forget that our daughter is married there'" (Genesis, a quarter } \\
\text { head and member of a traditional council) }\end{array}$ \\
\hline $\begin{array}{l}\text { "We have caves which are prohibited for some people to visit-the } \\
\text { people in the village had a belief that a cave is the house of the } \\
\text { non-living. The cave is preserved and whatever ecosystem that } \\
\text { exist there" (Paul is a support worker at a local university and } \\
\text { village elder) }\end{array}$ & $\begin{array}{l}\text { "We have certain taboos or restrictions. For instance, you will } \\
\text { be told it is a taboo to drink water from a certain pot if you have } \\
\text { done something the community considers to be evil" (Andrew } \\
\text { is a local chief) }\end{array}$ \\
\hline - Indigenous approach to climate change: & - Indigenous approach to communication: \\
\hline $\begin{array}{l}\text { "They plant trees around the compound to help to shield them with } \\
\text { shading and as windbreakers. If you go to their farms also, that is } \\
\text { what they do, they plant the trees around the place and the trees are } \\
\text { there to help them provide shelter for some of the plants so they } \\
\text { don't get too much heat or pushed to the ground" (Toni is a } \\
\text { researcher at a local university) }\end{array}$ & $\begin{array}{l}\text { "Drums in Africa are powerful symbols of communication. } \\
\text { When they are played, an elderly person can tell you what they } \\
\text { signal. If it's a rally for war or just for entertainment, an } \\
\text { elderly person will tell you that. So, drums have a language on } \\
\text { their own that can only be decoded by the elderly" (Genesis, a } \\
\text { quarter head and member of a traditional council) }\end{array}$ \\
\hline $\begin{array}{l}\text { "In most of the mountainous regions, most of the women have } \\
\text { realised that because of the physical structure of the land and } \\
\text { change of climate, they make their ridges horizontally to fight soil } \\
\text { erosion when it rains" (Elaine, director of a local NGO) }\end{array}$ & $\begin{array}{l}\text { "Our parents used storytelling to communicate. They taught } \\
\text { their children by the fireside where they tell them some stories } \\
\text { that convey some messages" (Alain is a community elder } \\
\text { and a clergy) }\end{array}$ \\
\hline - Indigenous approach to food preservation: & - Indigenous approach to health practice: \\
\hline $\begin{array}{l}\text { "They have their traditional way of conserving and saving food } \\
\text { that I think is part of their daily activities such as cassava grinding } \\
\text { to turn it into 'water fufu', 'garri', etc. Whilst cassava can't last, } \\
\text { 'garri' which is made from it can last" (Agnes is a PhD student) }\end{array}$ & $\begin{array}{l}\text { "My father himself was a traditionalist, if you had some kind of } \\
\text { illness and you come to him, he treats you. As an herbalist, he } \\
\text { just comes and sees you and then you go and harvest some } \\
\text { herbs. He combines them and gives you a concoction and you } \\
\text { get well" (Tabe is a village Elder) }\end{array}$ \\
\hline $\begin{array}{l}\text { "Our mothers will dig the ground and bury harvested cocoyams } \\
\text { inside-it keeps them fresh, otherwise if exposed, they can dry up. } \\
\text { So, they are buried in the ground and if you want to make a pot of } \\
\text { "Ekwang", you scratched the surface and remove a few cocoyam" } \\
\text { (Lyonga is a traditional ruler in one of the villages) }\end{array}$ & $\begin{array}{l}\text { "What we cannot really explain with some of these healing } \\
\text { practices is that the traditional healer knows where to cut the } \\
\text { plants and then they talk to the plants. You have some } \\
\text { incantations for it to become medicinal, if you don't do the } \\
\text { incantations it will not treat but once they do the incantations } \\
\text { it literally can treat the patients" (Toni is a researcher at a } \\
\text { local university) }\end{array}$ \\
\hline
\end{tabular}

The evidence of indigenous practices depicted in Table 2 hinge on aspects of environmental and societal sustainability, as a pointer to the possibility of a symbiotic relationship between scientific experts, indigenous people, their environmental and societal precepts, which is central to the notion of the socio-ecological university. Given these insights, it can be asserted that, at the level of the university and its mission to contribute towards sustainable development, it would be useful to emphasise the need for knowledge co-construction, implicated through partnerships with the university, building on indigenous knowledge base, thereby enabling societal transformation. Appropriate processes can ensure that all players-especially members of a "target population"-speak for themselves about ongoing strategies or practices they are employing which can engender sustainable development. In so doing, incorrect assumptions are prevented $[53,54]$ and relevant indigenous insights are integrated into collective mechanisms aimed at meeting societal and environmental development. Such mechanisms could be targeted, driven by curriculum design and re-design, based on local need and co-produced with the university $[15,28,55]$. In this light, the African continent and its universities can benefit from the appreciation and maximisation of indigenous culture [51,56]. The need to recognise indigenous people and their practices in processes aimed toward sustainable development is central to community development which entails collective participation [22]. The input of the community and stakeholder engagement is central to the idea of the socio-ecological university, underpinned by a symbiotic 
relationship. This relationship can enable universities to better calibrate their mission, enhancing possibilities for both societal and environmental concerns to be addressed through curriculum design.

\section{Maximising Indigenous Practices for Sustainable Development}

Whilst participants in their narratives duly expressed the indigenous approaches which hinge on environmental or societal sustainability, this paper is not intended to validate them. Several respondents did raise some concerns with some of the practices. These concerns can be categorised under the themes of gender bias, lack of quality control, the eroding effect of modernity and the absence of documentation. For instance, it was noted that some indigenous practices were gender bias-a respondent asserts: "There are gender rules and gender problems. There are traditions that are tied to gender. For example, women cannot own land. These traditions that are tied to gender sometimes bring limitation" (Elaine, director of a local NGO). This assertion underscores the need for gender equality in engendering sustainable development [57], and the maximisation of the developmental potentials of women for an equitable system.

Additionally, a limited number of participants alluded to the lack of quality control of the activities of some indigenous practitioners such as herbalists or traditional doctors, charlatans that have infiltrated the sector, necessitating a regulatory framework. A participant posits:

"There are charlatan healers in indigenous communities who take advantage and spoil certain issues because people are poor, there is unemployment so people who don't even have expertise will come in to take advantage of certain situations and they mess up". (Sharon, director of a local NGO)

Whilst there is need for an epistemic legitimisation of indigenous health practices (IHP), as it exposes the cultural richness inherent in them [58,59], there is also a need for quality control, as well as moderation of legislation, the negative narratives and associated terminologies. Furthermore, the dependency of IHP on ecosystems can have a degrading effect. This degrading effect can be evident in climate change, and loss of flora and fauna. This is driven in part by the commodification and commercialisation of indigenous healing products. Accordingly, measured and effective control can halt the abuse and exploitation of natural resources within the IHP scheme for the purpose of sustainability [60].

Some participants attributed the challenge associated with indigenous strategies toward sustainable development to the eroding effect of modernity. The following assertions support this claim:

"Modernity and western assimilation has taken us far, such that we are fast losing our culture, even our values are eroding away." (Alain is a community elder and a clergyman)

"Customary and indigenous communities are dying. They are gradually going out of existence and the traditional chiefs you have today are 'modern chiefs' - most of them have never been to the palace". (Terence is a researcher at a local university)

It can be argued that postcolonial society has aided the loss of indigenous knowledge [61] and practices through the predominance of Eurocentric knowledge taught in schools [36,37,62]. This has altered the habitus [63] of indigenous people and a sector such as farming has been affected. Agricultural yield and ability of local stakeholders to produce sustainable practices in their livelihoods have been tampered with due to modern interference. The lack of documentation of indigenous knowledge [61] was also perceived to be a challenge associated with the long-term catalytic effect of indigenous practices toward sustainable development. The following participants noted:

"The indigenous ways of doing things are not documented such that if the custodians die there will be no records for future generation". (Fred is a traditional ruler in one of the villages) 
"Indigenous knowledge is embedded in our indigenous languages and we are losing these languages. As the languages are dying off, there are lots of cultural belief systems and information that we are losing because people will not communicate more in that language and hence will not transmit that type of knowledge anymore". (Agnes, a PhD student at a local university)

These insights are a pointer to the need for the realisation of an enabling environment where indigenous knowledge systems and practices can flourish, and the university repositioned to maximise these for the common good of addressing both environmental and societal sustainability. To this end, the framework of the socio-ecologically-minded university can be posited as a possibility beyond the ecological university, which requires further consideration and nuanced understanding of the developmental learning context as espoused by Barnett [21].

\section{Possibilities of a Socio-Ecologically-Minded University}

Given its symbiotic context, underpinned by the South African principle of ubuntu, the idea of the socio-ecological university captures the notion of conscientious responsibility. This notion hinges on the premise of the university serving the public good, which can take the form of a holistic approach to sustainable development. Whilst the ecological university can function at a micro level (community and local spaces) that addresses environmental sustainability $[18,21,27]$, the socio-ecological university operates beyond the micro level by recognising the input of indigenous people aimed at tackling not just environmental issues but also core social development concerns, requiring wider stakeholder engagement. In achieving this end, the socio-ecological university seeks to create a symbiotic relationship for knowledge exchange with indigenous people, encapsulated in the spirit of ubuntu $[34,35]$. The following quotations from participants support the idea of a symbiotic relationship where there is mutually beneficial exchange of knowledge:

"When we had a chicken forum here, the Faculty of Agriculture brought out some farmers and their local breed chickens. Some of the local breed chickens were bigger than what we normally called the 'Agric fowls'. A researcher carried out research with one of the farmers to ascertain what he was feeding his chicken with and then brought that knowledge back to the laboratory at the university and try to see how he could enhance what made the local farmer's chicken looks healthier and bigger. So, he took an indigenous knowledge, brought it to the lab, made it better and showed it back to them". (Peter, researcher at a local university)

"If you bring a completely new knowledge into the community it may not sell. They must see the relationship between that knowledge and what they used to do. There must be a relationship between the two, without which you have to do a lot of communication". (Terence is a researcher at a local university)

"I think indigenous people can benefit from the university and the university will also benefit from the people because the people have wisdom, culture and a way of life you can write a book on or explore in terms of research. So, I think there should be a relationship between the traditional society and the university" (Genesis, a quarter head and member of a traditional council)

A symbiotic relationship between the university and indigenous people, for instance, can be framed within different sectors, and these are not limited to agriculture, biodiversity, climate change, medicine or food security $[17,30,39,53,61]$. Taking the contexts of biodiversity protection and agricultural production, indigenous knowledge can inform and shape methods of food cultivation, alongside conventional methods. Given that every knowledge system has a role to play in supporting the very fabric of the society, the socio-ecological university can also ensure that indigenous knowledge systems are not only recognised but documented for future development planning. Some research participants noted the following: 
"The first linkage is to document the knowledge. Indigenous knowledge may not be used again based on practice but on information left behind which was documented. After documentation, you can now address their need for capacity building. We need to document the knowledge as it is, so that we can get back to it sometime. In the course of documenting this knowledge, you build trust with the community". (Terence is a researcher at a local university)

"It will be good to archive or keep records of our indigenous practices for future generation".

(Linus, a traditional ruler in one of the villages)

The socio-ecologically-minded university can play a pivotal role in documenting indigenous knowledge and belief systems which can lead to the preservation of relevant practices, and other orally transmitted traditions $[33,53,60,61]$, which constitute the bedrock of sustainable development. Given these insights, the loss of indigenous language and strategies can be confronted, through a comprehensive framework inclusive of indigenous knowledge and justified through the need to look beyond the ecological premise. Such an approach could enable universities to better address the challenges of environmental and societal development drawn from a documentation of best practices.

\section{Conclusions}

The appreciation, documentation, inculcation and eventual implementation of indigenous practices and adaptations toward sustainable development are contingent on the curation of different knowledge systems by the university. The importance of the university in this respect is echoed by Etzkowitz [64] who identifies the university as a generative principle of knowledge-based societies in accordance with the triple-helix framework. Accordingly, universities can act as catalysts of development, forging new possibilities for the fulfilment of sustainable development. For this intersection to occur, the idea of the ecological university needs to be enhanced with a societal underpinning, built on a symbiotic framework - the socio-ecologically-minded university. This idea highlights an understanding of human resources within local communities and indigenous practices, and how the natural environment can be preserved for posterity. Central to the socio-ecologically-minded university is the need to implement a developmental, inclusive and engagement agenda, through the synthesis of knowledge and belief systems, and curriculum design, informed by a prioritisation of indigenous practices and ecosystems. Whilst the ecological university exists as an organism within its ecosphere at various levels-local, regional, national then internationally-the socio-ecological university validates the premise of a symbiosis of humans, and their external ecology as its core thesis. It emphasises the centrality of indigenous practices in creating a societal and environmentally-responsive approach, to the benefit of local stakeholders, enabling them to achieve sustainable solutions, aligned to the sustainable development goals (SDGs).

Author Contributions: Conceptualization, M.M. and C.F.; Writing—original draft, M.M.; Writing—review \& editing, C.F.

Funding: This research was initially funded by Bournemouth University's UoA23 and then by the QR funds of the School of Social Sciences at Nottingham Trent University, who also paid for the APC.

Acknowledgments: The authors are grateful to the anonymous reviewers for their valuable comments, and to Ikem Ifeobu and Carrie Paechter for insightful inputs and comments on the initial and final drafts respectively.

Conflicts of Interest: The authors declare no conflict of interest.

\section{References}

1. Ajayi, J.F. The African Experience with Higher Education; Ohio University Press: Athens, OH, USA, 1996.

2. Mazrui, A. Towards diagnosing and treating cultural dependency: The case of the African university. Int. J. Educ. Dev. 1992, 12, 95-111. [CrossRef]

3. Preece, J.; Ntseane, P.G.; Modise, O.M.; Osborne, M. The African university and community engagement in context. In Community Engagement in African Universities; Preece, J., Ntseane, P., Modise, O., Osborne, M., Eds.; National Institute of Adult Continuing Education: Leicester, UK, 2011. 
4. Mazrui, A. Churches and multinationals in the spread of modern education: A third world perspective. Third World Q. 1979, 1, 30-49. [CrossRef]

5. Zeleza, P.T. African studies and universities since independence. Transit. Int. Rev. 2009, 110-135. [CrossRef]

6. Collins, C.S.; Rhoads, R.A. The World Bank, Support for Universities, and Asymmetrical Power Relations in International Development. High. Educ. 2010, 59, 181-205. [CrossRef]

7. United Nations. United Nations Declaration on the Rights of Indigenous Peoples. 2007. Available online: https://www.un.org/development/desa/indigenouspeoples/declaration-on-the-rights-of-indigenouspeoples.html (accessed on 2 November 2019).

8. Weichselgartner, J.; Kasperson, R. Barriers in the science-policy-practice interface: Toward a knowledgeaction-system in global environmental change research. Glob. Environ. Chang. 2010, 20, 266-277. [CrossRef]

9. Wilson, S. Guest Editorial: What is an Indigenist Research Paradigm? Can. J. Native Educ. 2007, 30, 193-195, 322.

10. Mabizela, M. Private surge amid public dominance in higher education: The African perspective. J. High. Educ. Afr. 2007, 5, 15-38.

11. Mgaiwa, S.J.; Ishengoma, J.M. Institutional constraints affecting quality assurance processes in Tanzania's private universities. J. High. Educ. Afr./Revue de L'enseignement Supérieur en Afrique 2017, 15, 57-67.

12. Oanda, I. The evolving nature of student participation in university governance in Africa: An overview of policies, trends and emerging issues. In Student Politics in Africa: Representation and Activism; African Books Collective: Oxford, UK, 2016.

13. Chile, L.M.; Black, X.M. University-Community Engagement: Case Study of University Social Responsibility. Educ. Citizensh. Soc. Justice 2015, 10, 234-253. [CrossRef]

14. Etzkowitz, H. Research groups as 'quasi-firms': The invention of the entrepreneurial university. Res. Policy 2003, 32, 109-121. [CrossRef]

15. Lewis, L.A.; Kusmaul, N.; Elze, D.; Butler, L. The role of field education in a university-Community partnership aimed at curriculum transformation. J. Soc. Work Educ. 2016, 52, 186-197. [CrossRef]

16. Badat, $\mathrm{S}$. The challenges of transformation in higher education and training institutions in South Africa. Dev. Bank South. Afr. 2010, 8, 1-37.

17. Agrawal, A. Dismantling the divide between indigenous and scientific knowledge. Dev. Chang. 1995, 26, 413-439. [CrossRef]

18. Barnett, R.; Bengtsen, S. Universities and epistemology: From a dissolution of knowledge to the emergence of a new thinking. Educ. Sci. 2017, 7, 38. [CrossRef]

19. Wilson, S. Using Indigenist research to shape our future. In Decolonizing Social Work; Ashgate Publishing Limited: Surrey, UK, 2013; pp. 311-322.

20. Duke, J.M.; Borchers, A.M.; Johnston, R.J.; Absetz, S. Sustainable agricultural management contracts: Using choice experiments to estimate the benefits of land preservation and conservation practices. Ecol. Econ. 2012, 74, 95-103. [CrossRef]

21. Barnett, R. The coming of the ecological university. Oxf. Rev. Educ. 2011, 37, 439-455. [CrossRef]

22. Mbah, M.F. Towards the idea of the interconnected university for sustainable community development. High. Educ. Res. Dev. 2016, 35, 1228-1241. [CrossRef]

23. Boyer, E.L. Scholarship Reconsidered: Priorities of the Professoriate; Princeton University Press: Princeton, NJ, USA, 1990.

24. Savelyeva, T.; McKenna, J.R. Campus sustainability: Emerging curricula models in higher education. Int. J. Sustain. High. Educ. 2011, 12, 55-66. [CrossRef]

25. Sharp, L. Green campuses: The road from little victories to systemic transformation. Int. J. Sustain. High. Educ. 2002, 3, 128-145. [CrossRef]

26. Casper, A.M.A.; Balgopal, M.M. Conceptual change in natural resource management students' ecological literacy. Environ. Educ. Res. 2017, 24, 1159-1176. [CrossRef]

27. Persha, L.; Agrawal, A.; Chhatre, A. Social and ecological synergy: Local rulemaking, forest livelihoods, and biodiversity conservation. Science 2011, 331, 1606-1608. [CrossRef] [PubMed]

28. Villegas, A.M.; Lucas, T. Preparing Culturally Responsive Teachers: Rethinking the Curriculum. J. Teach. Educ. 2002, 53, 20-32. [CrossRef]

29. Cortese, A.D. The critical role of higher education in creating a sustainable future. Plan. High. Educ. 2003, 31, 15-22. 
30. Lee, W.; Meurk, C.; Clarkson, B. Agricultural intensification: Whither indigenous biodiversity? N. Z. J. Agric. Res. 2008, 51, 457-460. [CrossRef]

31. Mbah, M. Can local knowledge make the difference? Rethinking universities' community engagement and prospect for sustainable community development. J. Environ. Educ. 2019, 50, 11-22. [CrossRef]

32. Thornton, C.; Jaeger, A. The Role of Culture in Institutional and Individual Approaches to Civic Responsibility at Research Universities. J. High. Educ. 2008, 79, 160-182. [CrossRef]

33. Grange, L. Ubuntu, ujaama, environment and moral education. J. Moral Educ. 2012, 41, 329-340. [CrossRef]

34. Ramose, M.B. In search of an African philosophy of education: Perspectives on higher education. S. Afr. J. High. Educ. 2004, 18, 138-160.

35. Waghid, Y. African philosophy of education reconsidered. In on Being Human; Routledge: London, UK, 2014.

36. Barongo-Muweke, N. The need for localizing research-decolonization of knowledge generation. In Decolonizing Education; Springer: New York, NY, USA, 2016; pp. 239-247.

37. Higgs, P.; Moeketsi, R.M.H. The Africanisation of academic development programs: A case study. Indilinga Afr. J. Indig. Knowl. Syst. 2012, 11, 146-159.

38. Thaman, K.H. Decolonizing Pacific studies: Indigenous perspectives, knowledge, and wisdom in higher education. Contempor. Pac. 2003, 15, 1-17. [CrossRef]

39. Nyong, A.; Adesina, F.; Elasha, B.O. The value of indigenous knowledge in climate change mitigation and adaptation strategies in the African Sahel. Mitig. Adapt. Strategy. Glob. Chang. 2007, 12, 787-797. [CrossRef]

40. Van Damme, L.S.M.; Neluvhalani, E.F. Indigenous knowledge in environmental education processes: Perspectives on a growing research arena. Environ. Educ. Res. 2004, 10, 353-370. [CrossRef]

41. Stake, R.E. The Art of Case Study Research; Sage: London, UK, 1995.

42. Yin, R.K. Validity and generalization in future case study evaluations. Evaluation 2013, 19, 321-332. [CrossRef]

43. Njeuma, D.L.; Endeley, H.N.; Mbuntum, F.F.; Lyonga, N.; Nkweteyim, D.; Musenja, S.; Elizabeth, E. Reforming a National System of Higher Education: The Case of Cameroon. 1999. Available online: https://www.voced.edu.au/content/ngv\%3A69680 (accessed on 23 July 2019).

44. Browne, K. Snowball sampling: Using social networks to research non-heterosexual women. Int. J. Soc. Res. Methodol. 2005, 8, 47-60. [CrossRef]

45. Farquharson, K. A different kind of snowball: Identifying key policymakers. Int. J. Soc. Res. Methodol. 2005, 8, 345-353. [CrossRef]

46. Rubin, H.J.; Rubin, I.S. Qualitative Interviewing: The Art of Hearing Data; Sage: Thousand Oaks, CA, USA, 2012.

47. Aronson, J. A pragmatic view of thematic analysis. Qual. Rep. 1995, 2, 1-3.

48. Ryan, G.W.; Bernard, H.R. Techniques to identify themes. Field Methods 2003, 15, 85-109. [CrossRef]

49. Crilly, N.; Blackwell, A.F.; Clarkson, P.J. Graphic elicitation: Using research diagrams as interview stimuli. Qual. Res. 2006, 6, 341-366. [CrossRef]

50. Briggs, J. Indigenous knowledge: A false dawn for development theory and practice? Prog. Dev. Stud. 2013, 13, 231-243. [CrossRef]

51. Fonchingong, C.C. Optimising Community-Driven Development Through Sage Tradition in Cameroon. Glob. Soc. Welf. 2018, 5, 145-153. [CrossRef]

52. Sillitoe, P. The development of indigenous knowledge: A new applied anthropology. Curr. Anthropol. 1998, 39, 223-252. [CrossRef]

53. Kihila, J.M. Indigenous coping and adaptation strategies to climate change of local communities in Tanzania: A review. Clim. Dev. 2018, 10, 406-416. [CrossRef]

54. Lasker, R.D.; Guidry, J.A. Engaging the Community in Decision Making: Case Studies Tracking Participation, Voice and Influence; McFarlan and Company: Jefferson, NC, USA, 2009.

55. Engel-Di Mauro, S.; Carroll, K.K. An African-centred approach to land education. Environ. Educ. Res. 2004, 20, 70-81. [CrossRef]

56. Wallerstein, N.; Bernstein, E. Empowerment education: Freire's ideas adapted to health education. Health Educ. Q. 1988, 15, 379-394. [CrossRef] [PubMed]

57. Regmi, P.P.; Weber, K.E. Achieving sustainable agriculture through recognizing gender roles: Some salient points. Gend. Technol. Dev. 1997, 1, 225-245. [CrossRef] [PubMed]

58. Harley, D.A. Indigenous healing practices among rural elderly African Americans. Int. J. Disabil. Dev. Educ. 2006, 53, 433-452. [CrossRef] 
59. Marks, L. Global Health Crisis: Can indigenous healing practices offer a valuable resource? Int. J. Disabil. Dev. Educ. 2006, 53, 471-478. [CrossRef]

60. Anyinam, C. Ecology and ethnomedicine: Exploring links between current environmental crisis and indigenous medical practices. Soc. Sci. Med. 1995, 40, 321-329. [CrossRef]

61. Ngulube, P. Managing and preserving indigenous knowledge in the knowledge management era: Challenges and opportunities for information professionals. Inf. Dev. 2002, 18, 95-102. [CrossRef]

62. Glasson, G.E.; Mhango, N.; Phiri, A.; Lanier, M. Sustainability science education in Africa: Negotiating indigenous ways of living with nature in the third space. Int. J. Sci. Educ. 2010, 32, 125-141. [CrossRef]

63. Bourdieu, P. Cultural reproduction and social reproduction. In Knowledge, Education and Social Changes; Taylor \& Francis: London, UK, 1974.

64. Etzkowitz, H. The Triple Helix: University-Industry-Government Innovation; Routledge: London, UK, 2008.

(C) 2019 by the authors. Licensee MDPI, Basel, Switzerland. This article is an open access article distributed under the terms and conditions of the Creative Commons Attribution (CC BY) license (http://creativecommons.org/licenses/by/4.0/). 